of the general type $R \mathrm{OCONHOH}$, where $R=\mathrm{C}_{2} \mathrm{H}_{5}$ $\mathrm{CH}_{3}\left(\mathrm{CH}_{2}\right)_{2}$, and $\mathrm{CH}_{3}\left(\mathrm{CH}_{2}\right)_{3}$, gave similar bands centred near $3,300 \mathrm{~cm}^{-1}$. Hydroxyurea showed a similar absorption, but with the bands due to the asymmetric and symmetric modes of the $\mathrm{NH}_{2}$ group superimposed at $3,422 \mathrm{~cm}^{-1}$ and $3,315 \mathrm{~cm}^{-1}$, respectively. (c) The compound was unstable in alkaline media yielding hydroxyurea (III) and cyanic acid (IV) (detected and estimated via its blue $\mathrm{Co}^{2+}$ complex) as two of the decomposition products. (d) On treatment with diazomethane in methanol-ether, the compound yiolded $N, N^{\prime}$-dimethoxyurea (V) as a major reaction product which was identical with the authentic substance synthesized by reaction of phosgene with $O$-methylhydroxylamine. (e) With benzoyl chloride in pyridine at $0^{\circ}$, it yielded $N, N^{\prime}, O, O^{\prime}$-tetrabenzoyldihydroxyurea (VI), which, in boiling aqueous ethanol, yielded $O$-benzoyl benzohydroxamic acid (VII).

Preliminary experiments indicate that dihydroxyurea is more than five times as active as hydroxyurea in the induction of chromosomal aberrations in the root tips of Vicia faba (S. H. Revell, personal communication).

We thank Dr. S. H. Revell and Miss K. S. Peggie for the experiments with Vicia faba, and Dr. R. Lumley Jones for the infra-red determinations. This work was supported by grants to this Institute from the Medical Research Council and the British Empire Cancer Campaign for Research, and by the Public Health Service Research grant $C A-03188-08$ from the National Cancer Institute, U.S. Public Health Service.

E. Boyland

R. NERY

Chester Beatty Research Institute, Institute of Cancer Research, Royal Cancer Hospital, Fulham Road, London, S.W.3.

${ }^{1}$ Borenfreund, E., Krim, M., and Bendich, A., J. Nat. Cancer Inst., 32, 667 (1964).

${ }^{2}$ Somers, C. F., and Hsu, T. C., Proc. U.S. Nat. Acad. Sci., 48, 937 (1962).

${ }^{3}$ Boyland, E., Nery, R., Peggie, K. S., and Williams, K., Biochem. J., 89, $113 \mathrm{P}$ (1963).

- Sterns, B., Losee, K. A., and Bernstein, J., J. Med. Chem., 6, 201 (1963).

${ }^{5}$ Fishbein, W. N., and Carbone, P. P., Science, 142, 1069 (1963).

6 Boyland, E., and Nery, R., Biochem. $J$. (in the press).

\section{Concentrating Protein Solutions}

THE earliest method of concentrating solutions of labile proteins, drying from the frozen state in vacuo, has several disadvantages, some of a technical and others of a fundamental nature such as increase in salt concentration and the proneness of complexes of proteins with lipids and some other substances to denaturation on freezing and drying. The alternatives are removal of water by dialysis of the protein solution against concentrated solutions of dextran or polyethylene glycol ${ }^{1}$ of molecular weights sufficiently high not to penetrate the walls of the 'Cellophane' dialysis sac, or absorption of the water by shaking the protein solution with dispersed, cross-linked dextran ('Sephadex')2. These methods avoid freezing and drying and allow the salt concentration to be maintained at any desired value. Howover, dialysis is time-consuming to set up if many small samples are involved, and considerable losses can occur on the walls of the sac when the removal of $0.1-0.5$ $\mathrm{ml}$. of viscous protein solution is attempted. Removal of the water with 'Sephadex' is simple to carry out, but there is sometimes considerable loss of trace proteins by adsorption on to the large surface presonted by the gel particles. This led me to consider the possibility of using rods of dried hydrophilic gel to remove the water from protein solutions while maintaining constant ionic strength.

The rods used in the experiments were prepared by polymerizing an aqueous solution containing acrylamide
$(15.2 \mathrm{~g} / 100 \mathrm{ml}$.$) and N, N$-methylenebisacrylamide $(0 \cdot 8$ $\mathrm{g} / 100 \mathrm{ml}$.) in silicone-coated $0.5 \mathrm{~cm} \times 20 \mathrm{~cm}$ glass tubes. In the course of diffusion experiments it has been established that substances with molecular weights greater than 10,000 do not significantly penetrate acrylamide gels of this degree of cross-linking and concentration (Curtain, unpublished results). Polymerization was initiated by adding $0.4 \mathrm{~g}$ of ammonium persulphate and $0.2 \mathrm{ml}$. of dimethyl amino-propionitrile to each $100 \mathrm{ml}$. of monomer solution. For convenience in handling the activated mixture, polymerization could be retarded for $15 \mathrm{~min}$ by adding $100 \mathrm{mg}$ of potassium ferricyanide to each $100 \mathrm{ml}$. of solution. The silicone-coated glass tubes were prepared by dipping air-dried, acid-washed glass tubes in undiluted General Electric 'Drifilm' chlorosilane for 30 sec. The tubes were then washed for $10 \mathrm{~min}$ in running distilled water and dried in an oven at $150^{\circ} \mathrm{C}$ for $2 \mathrm{~h}$. The life of the coating appears to be indefinite.

The rods of polymerized gel were removed from the tubes by pushing with a close-fitting glass rod and washed with six twelve-hourly changes of excess distilled water. They were then eut into convenient lengths (3-6 cm) and exposed in an open dish to the draught from the cooling unit of a $4^{\circ} \mathrm{C}$ cold room. After $96 \mathrm{~h}$ the rods had dried to 20 per cent of their original diameter and 90 per cent of their original length. It was found that more rapid drying at higher temperatures produced cracks in the rods. The rods may be kept indefinitely in a desiccator over phosphorus pentoxide. On equilibration with water for $18 \mathrm{~h}$ the rods attained their original volume, indicating a water regain of approximately $5 \cdot 2 \mathrm{~g} / \mathrm{g}$.

For drying, protein solutions were placed in a testtube of a diameter 3-4 $\mathrm{mm}$ greater than that of the swollen diameter of the rod $(0.75 \mathrm{~cm})$. A length of dry rod was then dropped into the protein solution. The amount of rod required to effect a given reduction in volume may be calculated readily from the water regain of the gel. In practice it was found that a ten-fold concentration could be obtained easily with volumes as low as $1 \mathrm{ml}$. For smaller volumes thinner rods $(0.4 \mathrm{~cm})$ were tried and in this case it was found practicable to concentrate volumes of $0.4 \mathrm{ml}$. down to $0.04 \mathrm{ml}$.

Possible loss of protein or denaturation was measured in two ways. $2 \mathrm{ml}$. of serum was concentrated to $0.2 \mathrm{ml}$. and then diluted to $2 \mathrm{ml}$. with 0.9 per cent $(\mathrm{w} / \mathrm{v})$ sodium chloride solution. Samples of the original serum and samples of the concentrated and diluted serum were examined by moving boundary electrophoresis and by micro-immunoelectrophoresis. The moving boundary electrophoresis was carried out in a Tiselius apparatus fitted with the phase-plate gradient interferometric optical system of Moore and Opperman ${ }^{3}$ using $p \mathbf{H}$ $8 \cdot 6, I=0 \cdot 1$ sodium veronal buffer. Duplicate runs of each sample were carried out and the ordinates of the gradient curves obtained by measurement of the interference fringe ${ }^{4}$ directly compared for each run. Recovery of all components averaged 100 per cent within the limits of precision of the techniques used $(0.7$ per cent). The micro-immunoelectrophoretic patterms of the two samples were enantiographic, suggesting that no alteration had occurred in any of the components resolved by this technique.

I thank Dr. A. Baumgarten for carrying out the immunoelectrophoresis run.

\section{Curtain}

Baker Medical Research Institute,

Commercial Road, s.1, Victoria, Australia.

I Kohn, J. A., Nature, 183, 1055 (1959).

2 Flodin, P., Gelotte, B., and Porath, J., Nature, 188, 493 (1960).

${ }^{3}$ Moore, D. H., and Opperman, K., Biochim. Biophys. Acta, 22, 136 (1956).

" Curtain, C. C., J. Instrum. Sci., 37, 190 (1960). 